\title{
STUDIES ON ESTIMATION OF LEAF GAS EXCHANGE OF ORNAMENTAL WOODY PLANT SPECIES
}

\author{
FORRAI, M. ${ }^{1}$ *-SÜTÖRINÉ DIÓSZEGI, M. ${ }^{1}$ - LADÁNYI, M. ${ }^{2}$ - HONFI, P. ${ }^{1}$ - HROTKÓ, K. ${ }^{1}$ \\ ${ }^{1}$ Corvinus University Budapest, Department of Floriculture and Dendrology \\ 1118 Budapest, Villányi út 29-43., Hungary \\ (phone: +36-1-482-6462) \\ ${ }^{2}$ Corvinus University of Budapest, Department of Mathematics and Informatics \\ 1118 Budapest, Villányi út 29-43., Hungary \\ (phone: +36-1-482-6261; fax: +36-1-466-9273) \\ *Corresponding author \\ e-mail: mihaly.forrai@uni-corvinus.hu
}

(Received 24 $4^{\text {th }}$ October 2011; accepted $15^{\text {th }}$ May 2012)

\begin{abstract}
Instrumental measurements were carried out on urban tolerant Acer, Fraxinus, and Tilia

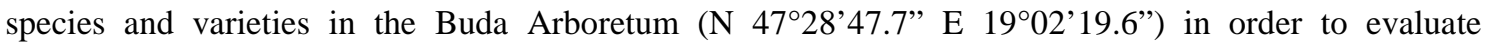
differences between their photosynthetic and gas exchange performance. Stomatal conductance, transpiration, net photosynthesis and photosynthetic active radiation (PAR) on sample leaves were measured and calculated using the LCi infrared gas analyzer (IRGA). Meanwhile the photosynthetic activity (net $\mathrm{CO}_{2}$ assimilation) of leaves showed correlation to PAR, stomatal conductance and leaf temperature, there are significant differences found between genera and species of urban trees, which suggests that their $\mathrm{CO}_{2}$ assimilation capacity differs. This influences the value of genera and species considering the urban air cleaning due to their $\mathrm{CO}_{2}$ fixation. Under the examined conditions leaves of Tilia sp. showed higher photosynthetic capacity compared to Acer or Fraxinus sp. The transpiration rate of leaves correlates to stomatal conductance and leaf temperature. The low transpiration rate of Fraxinus excelsior 'Westhof's Glorie' leaves suggests more economic water use. We also found considerable differences in water use efficiency (WUE) between species and genera. Tilia sp. Acer platanoides and Fraxinus excelsior 'Westhof's Glorie' showed higher WUE compared to Acer negundo.
\end{abstract}

Keywords: $\mathrm{CO}_{2}$ fixation, stomatal conductance, transpiration rate, water use efficiency, urban trees

\section{Introduction}

Due to a long selection process the studied tree species and varieties (Fraxinus excelsior 'Westhof's Glorie', Tilia tomentosa 'VI', Acer platanoides 'Crimson King') adapted well to urban climate. Besides their aesthetical and theoretical values the currently used species and varieties in urban areas also help to make the human environment much more comfortable due to their $\mathrm{CO}_{2}$ fixation and water vapour emission. Calculations were made recently to estimate their value expressed in money to aid the efforts of protecting the trees (Radó, 1999; Jószainé Párkányi, 2007). There is little information about the yield on environmental benefits of urban trees and there are only few references about systematic measurements.

Knowledge about the $\mathrm{CO}_{2}$ fixation and water vapour emission of trees and shrubs has to be confirmed with onsite instrumental examinations to get actual information. There are little reliable data about LAI values and photosynthetic activity of such trees and shrubs which are exposed to various stress factors (air pollution, drought, human impacts) in different environmental conditions. Trees in urban spaces are exposed to several harmful factors (heavy metal accumulation on and in them, drought- and heat 
stress, human impacts), so it can easily be seen that these trees have to cope with significantly different conditions than the ones living in forests.

Series of measurements began in autumn 2010. The aim of our in situ instrumental examination on urban park-trees was to evaluate their photosynthetic activity, water use efficiency and developing methodology for accurate instrumental examination, which can be used in cities and can estimate the trees' health state, photosynthetic activity and their impact on the urban microclimate and air quality.

\section{Review of literature}

There are estimated values for $\mathrm{CO}_{2}$ assimilation and $\mathrm{H}_{2} \mathrm{O}$ emission mainly from earlier studies under forest conditions carried out on trees between 20 and 90 years of age (Radó, 2001). Urban climate, of course, creates different environmental conditions. Several studies emphasized the importance of environmental conditions for leaf gas exchange. Endres et al. (2009) found that light environment influence the $\mathrm{CO}_{2}$ fixation. The correlation between PAR (photosynthetic active radiation) and photosynthetic rate of Tabebuia chrysotricha differs depending on light environment: the correlation was stronger $\left(\mathrm{R}^{2}=0.6699\right)$ at plants grown under shade and lower $\left(\mathrm{R}^{2}=0.29\right)$ at plants grown in sunlight. They also found different correlation levels between PAR and leaf temperature $\left(\mathrm{R}^{2}=0.86\right.$ under shade; $\mathrm{R}^{2}=0.25$ in sunlight), and between PAR and water use efficiency $\left(R^{2}=0.71\right.$ under shade; $R^{2}=0.4299$ in sunlight). Fini et al. (2010) studied the effect of light environment to leaf gas exchange and found that response to shade is species-specific. Rhododendron hybr. responded to shading by decreasing its transpiration and stomatal conductance. Shading increased carbon assimilation of Choisya ternate while Viburnum $\times$ pragense showed a great adaptability to the different light environments: plants grown in full sun and under $60 \%$ shade had similar leaf gas exchange. Several studies on woody species have found increased photosynthetic activity in elevated $\mathrm{CO}_{2}$ in controlled circumstances (Ceulemans and Mousseau, 1994; Curtis, 1996; Heath and Kerstiens, 1997).

In Spain, Gortan et al. (2009) measured daytime stomatal conductance on Fraxinus ornus in different drainage places and the average value was $0.3-0.4 \mu \mathrm{mol} \mathrm{m} \mathrm{m}^{-2} \mathrm{~s}^{-1}$, the maximum measured value was $0.58 \mu \mathrm{mol} \mathrm{m} \mathrm{m}^{-2} \mathrm{~s}^{-1}$. In Switzerland, Leuzinger et al. (2010) measured midday stomatal conductance in park and street circumstances and the results ranged from 0.124 to $0.247 \mu \mathrm{mol} \mathrm{m}^{-2} \mathrm{~s}^{-1}$ for all measured species, for example Tilia tomentosa $\left(0.193 \mu \mathrm{mol} \mathrm{m} \mathrm{s}^{-1}\right)$, Acer platanoides $\left(0.143 \mu \mathrm{mol} \mathrm{m}^{-2} \mathrm{~s}^{-1}\right)$ and Platanus acerifolia $\left(0.247 \mu \mathrm{mol} \mathrm{m} \mathrm{m}^{-2}\right)$.

Several studies showed wide range of stomatal conductance measured on woody plants. On Tabebuia chrysotricha, Endres et al. (2009) measured average $0.14 \mu \mathrm{mol} \mathrm{m}^{-2} \mathrm{~s}^{-1}$ stomatal conductance in full bright and average $0.15 \mu \mathrm{mol} \mathrm{m}^{-2} \mathrm{~s}^{-1}$ under shade. Rodrigues et al. (2010) measured daily stomatal conductance from 8:00 to 18:00 and found maximum stomatal conductance in the morning on Artocarpus heterophyllus $\left(0.78 \mu \mathrm{mol} \mathrm{m}^{-2} \mathrm{~s}^{-1}\right)$ and at noon on Annona squamosa $\left(0.93 \mu \mathrm{mol} \mathrm{m} \mathrm{s}^{-2}\right)$.

Although it is generally assumed that stomata close at night, Daley and Phillips (2006), Snyder et al. (2003), Bucci et al. (2004) and Grulke et al. (2004) measured stomatal opening in some species. For example Daley and Phillips (2006) measured that the stomatal conductance dropped just by $25 \%$ in Betula papyrifera, but in Quercus rubra and Acer rubrum they measured the stomatal conductance approaching to zero. 
Considering the water use of Tamarix chinensis, Anderson (1982) measured that the plant transpires more than its own fresh mass each hour in bright sunlight conditions.

The measurements of photosynthetic activity and transpiration rate of the leaves are frequently used tools on horticultural crops, but raises questions of methodology when applied on urban trees. On fruit trees it has a great significance as a great part of the light energy absorbed by the leaves can be turned into yield (Hrotkó, 2002). Gyeviki (2011) measured $9-17 \mu \mathrm{mol} \mathrm{m}^{-2} \mathrm{~s}^{-1} \quad \mathrm{CO}_{2}$ fixation and $4-10 \mathrm{mmol} \mathrm{m}^{-2} \mathrm{~s}^{-1}$ transpiration on cherry (Prunus avium) leaves in field conditions, while also on cherry, Noitsakis and Nastis (1995) reported $3-4 \mathrm{mmol} \mathrm{m}^{-2} \mathrm{~s}^{-1}$ and $10-20 \mathrm{mmol} \mathrm{m}^{-2} \mathrm{~s}^{-1}$ transpiration, in field and under shelter, respectively.

\section{Materials and methods}

We have chosen sample trees for the measurements (species from Tilia, Acer and Fraxinus genera) which are suitable for modelling urban park- or street-trees. For the sake of proper statistical evaluation and data comparability measurements were made in bright sunny weather (average temperature: $20.2{ }^{\circ} \mathrm{C}$, air humidity: $57.67 \%$, maximum wind blow: $7.63 \mathrm{~m} \mathrm{~s}^{-1}$ ) in the middle of September.

For the measurements we have chosen differently located trees in Buda Arboretum. The leaf gas exchange was measured using the LCi equipment on 10 leaves per tree in 4-5 repetitions, so in all we got 40-50 measurements on single leaves per each variety of trees.

To measure the photosynthetic activity, an infrared gas analyzer was used (LCi device of ADC Scientific Ltd.). It measured and calculated various parameters such as the $\mathrm{H}_{2} \mathrm{O}$ and $\mathrm{CO}_{2}$ exchange rates of the leaves, the atmospheric pressure, the temperature, the PAR (photosynthetic active radiation) value at the surface of the leaf, the $\mathrm{CO}_{2}$ concentration between cells, the transpiration and stomatal conductance.

From among the measured data the photosynthetic active radiation (PAR), the surface temperature of the measured leaf, the transpiration rate, the stomatal conductance, the photosynthetic rate and water use efficiency (WUE) were evaluated.

The statistical analysis of data was carried out using the statistical software PASW18. Since the data were positively skewed and/or strongly kurtic, first a Box and Cox (1964) transformation was made. As the examined variables are strongly correlated we run a multivariate overall analysis of variance (MANOVA) with a fixed factor of the species and a follow-up between-subject analysis. We calculated the observed power using alpha $=0.05$ and we also considered the effect size measure (denoted by partial $\eta^{2}$ ) which gives the variance explained by a given explaining variable of the variance remaining after excluding variance explained by the other variables. Normality of the residuals of the MANOVA model was checked with d'Agostino (1990) test. Homogeneity of variances was tested with Levene test and in case the result was insignificant ( $p>0.05$ ) we run a Tukey post hoc test, while in case it failed, we applied Games-Howell post hoc test, both indicate significance differences at $\mathrm{p}<0.05$ level. 
Correlation and multiple regression analyses were conducted to examine the relationship amongst stomatal conductance, transpiration, photosynthesis, leaf temperature and PAR in different model structures written in general form of

$$
Y=p_{0}+p_{1} X_{1}+p_{2} X_{2}+p_{3} X_{3}+p_{4} X_{4}+\varepsilon,
$$

where $Y$ denotes the dependent variable (chosen one from leaf surface temperature, transpiration rate, stomatal conductance and photosynthetic rate),

$X_{i}$ denote the explaining variables (selected suitably from variables PAR, surface temperature, transpiration rate, stomatal conductance and photosynthetic rate), multiplied by coefficients $p_{i}$ and

$\varepsilon$ denotes the normally distributed error term with zero expectation.

The explaining variables were chosen with stepwise method as the significance level of the $F$ value of the model was below 0.05 and were removed from the model if the significance of the $F$ value was over 0.1 . The parameter estimations were tested with ttest. Normality of the error terms was proved with d'Agostino (1990) test ( $p>0.05$ ). Since there was significant correlation between explaining variables, the tolerance was also calculated for each explaining variable. In case the tolerance was below 0.1 , the model was reduced to a smaller number of explaining variables.

\section{Results and discussion}

During our measurements in Buda Arboretum in autumn 2010, leaves of Acer, Fraxinus and Tilia genera were investigated with the LCi device. The overall MANOVA test was significant (Wilk's lambda=0.027; $\mathrm{p}<0.001$ ). The between-subject ANOVA was significant for all variables $(\mathrm{p}<0.001)$ with observed power higher than 0.99 . The effect size was the highest of leaf surface temperature (partial $\eta^{2}=0.219$ ) followed by the ones of transpiration and stomatal conductance (partial $\eta^{2}=0.581 ; 0.406$, respectively). The effects of photosynthetic rate of leaves, water use efficiency and photosynthetic active radiation are low (partial $\eta^{2}=0.379 ; 0.290 ; 0.219$, respectively).

\section{Photosynthetic active radiation (PAR) values measured on leaf}

Considering the absorbed PAR values it is clearly visible that the measured trees were located in different PAR-exposed conditions (Fig. 1). The different PAR may greatly influence the photosynthetic activity of plants (Endres et al., 2009). These values were measured in a period from 12 am to $14 \mathrm{pm}$ which means the highest radiation during the day. The more shaded Acer platanoides and Tilia tomentosa 'Balaton' trees were exposed to significantly lower PAR exposition compared to the free standing, sunexposed Tilia cordata. This should be considered in further evaluation. 


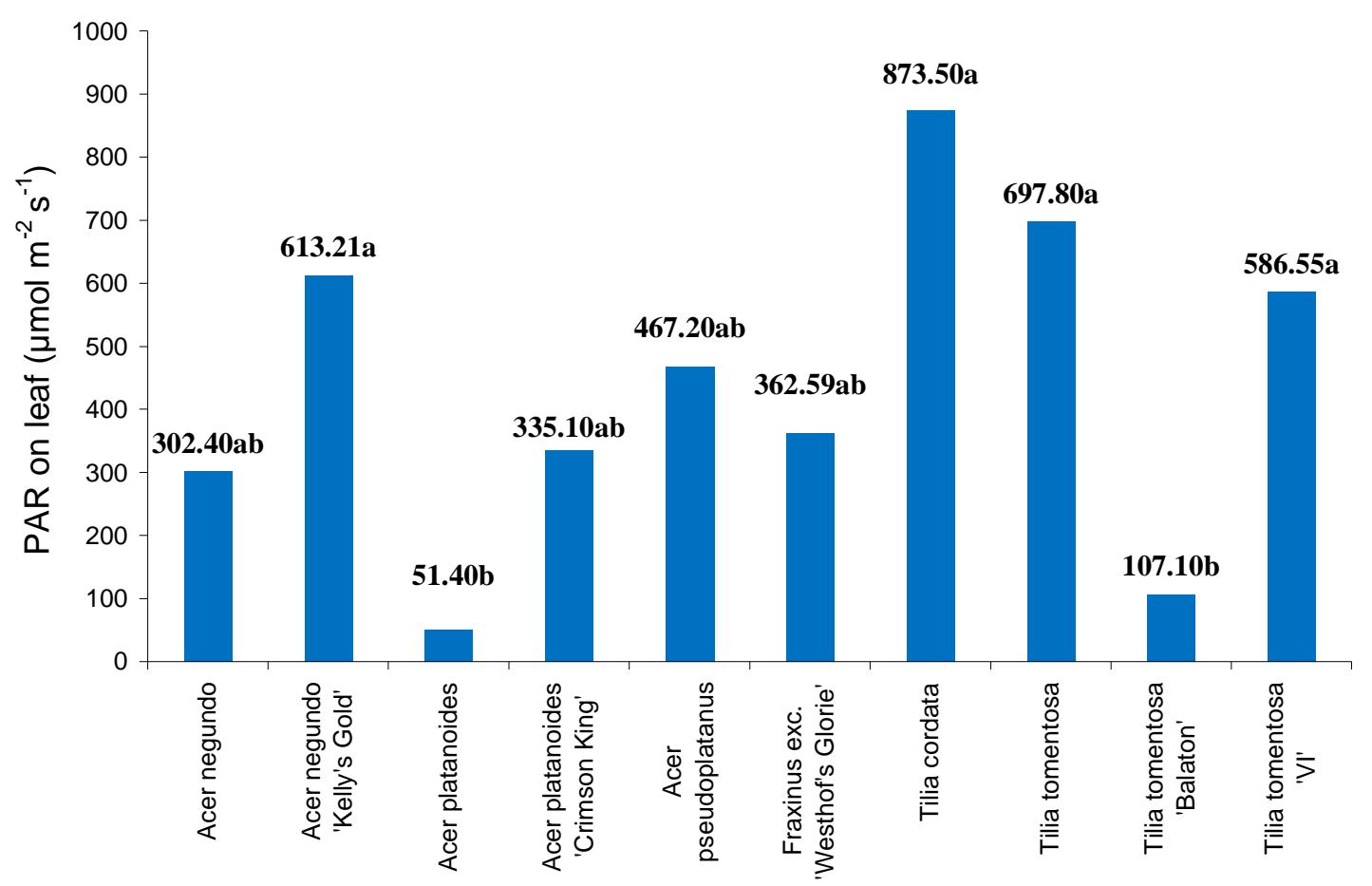

Figure 1. Average PAR values on leaves $\left(\mu \mathrm{mol} \mathrm{m} \mathrm{m}^{-2} \mathrm{~s}^{-1}\right)$ of the measured plants. Different letters mean significant differences according to Games-Howell post hoc test ( $p<0.05)$.

\section{Leaf surface temperature}

Considering leaf surface temperature there are significant differences found between the trees of different genera (Fig 2).

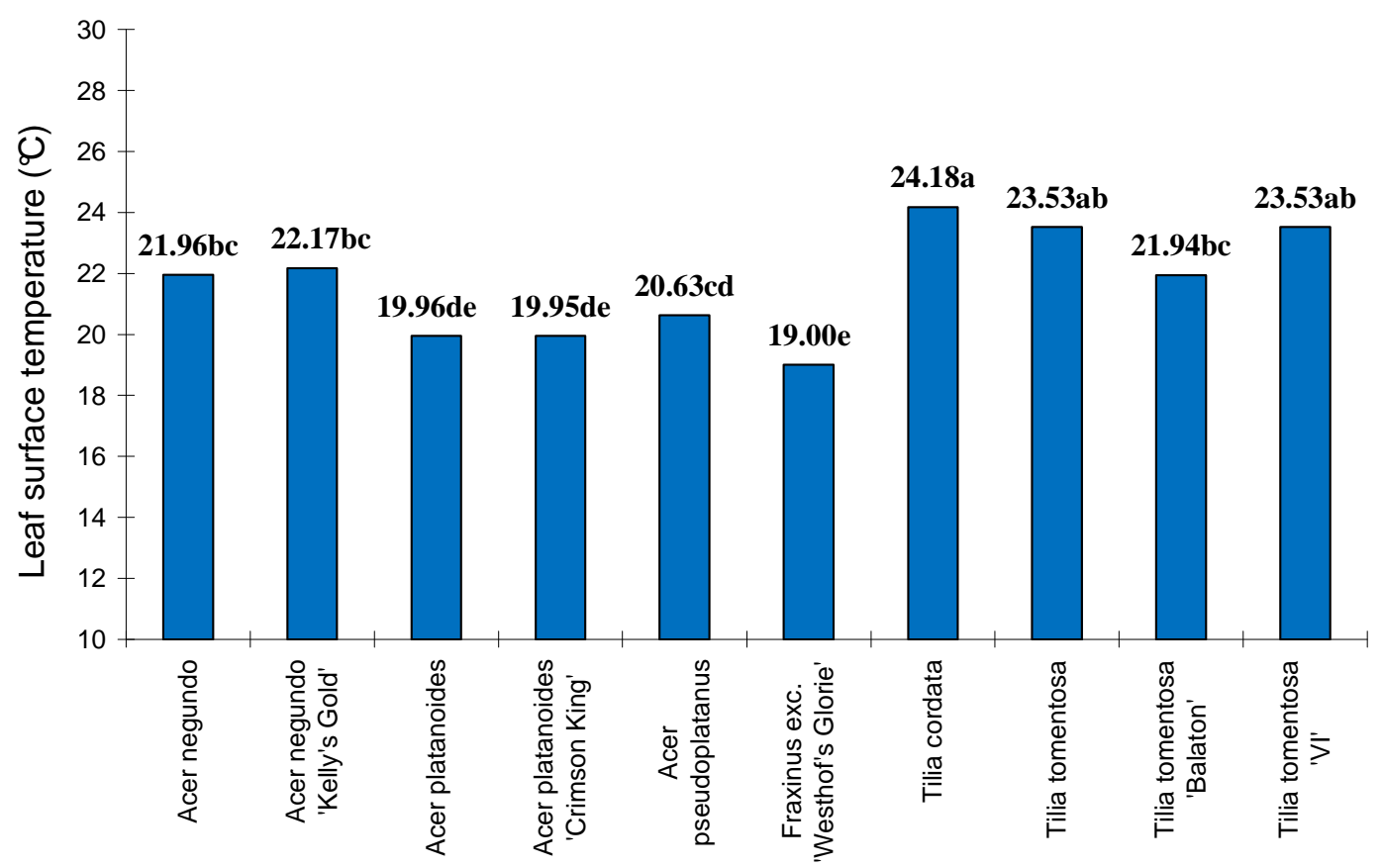

Figure 2. Leaf surface temperature $\left({ }^{\circ} \mathrm{C}\right)$ with the mean values of the measured plants. Different letters mean significant differences according to Games-Howell post hoc test ( $p<0.05)$. 
Within genus Tilia the low PAR exposed 'Balaton' did not show significant lower leaf temperature. Despite the great difference in PAR absorption, there is no significant difference in leaf surface temperature either within Acer species, or within Acer negundo. However, the PAR absorption differences are reflected in the leaf temperature, so we can say that the leaf surface temperature of the plant can be a subject of genera features under similar environmental conditions.

The results showed that at the same time and under same conditions three species of Tilia genus had the highest leaf surface temperature when PAR exposition was similar. The low PAR-exposed Tilia tomentosa 'Balaton' had some lower leaf surface temperature but it is not proportional to the low PAR values. Species from the Fraxinus genus had significantly the lowest leaf surface temperature in the measured period (Fig. 2) though the PAR exposition of the leaves was intermediate.

Table 1. Regression diagnostics of the model of leaf surface temperature $\left({ }^{\circ} \mathrm{C}\right)$

\begin{tabular}{|c|c|c|c|c|c|c|c|c|}
\hline & odel & $\mathrm{C}=\mathrm{D}^{2}$ & & motarc & & Toler- & $F$ with & $\begin{array}{l}\text { Variance } \\
\text { explained }\end{array}$ \\
\hline $\begin{array}{c}\text { Dependent } \\
\text { variable }\end{array}$ & $\begin{array}{c}\text { Explaining } \\
\text { variables }\end{array}$ & Corr. K & & meters & $t$ & ance & df & $\begin{array}{l}\text { by the } \\
\text { model }\end{array}$ \\
\hline & constant & & $p_{0}$ & 17.435 & $73.52 * * *$ & - & & \\
\hline & transpiration & $0.723 * *$ & $p_{1}$ & 5.497 & $14.45^{* * *}$ & 0.146 & & \\
\hline $\begin{array}{l}\text { Leaf surface } \\
\text { temperature }\end{array}$ & $\begin{array}{l}\text { photosyntheti } \\
\text { c rate }\end{array}$ & $0.570 * *$ & $p_{2}$ & 0.172 & $6.00^{* * *}$ & 0.612 & $\begin{array}{c}130.34 \\
* * *\end{array}$ & $0.777 * * *$ \\
\hline & $\begin{array}{c}\text { stomatal } \\
\text { conductance }\end{array}$ & $0.504 * *$ & $p_{3}$ & -38.527 & $-10.65 * * *$ & 0.14 & & \\
\hline
\end{tabular}

$* \mathrm{p}<0.05 ; * * \mathrm{p}<0.01 ; * * * \mathrm{p}<0.001$

Table 1 summarizes the regression analysis results: the bivariate correlation between the leaf surface temperature and the explaining variables such as transpiration, photosynthetic rate and stomatal conductance, the estimated parameters, the $t$ values of the estimated parameters, the tolerance of the model variables, the $F$ value of the ANOVA model test with its degrees of freedom and the variance explained by the model.

Table 1 shows that the leaf temperature depends from the tree's non-environmental conditions which is indicated by the significant correlation between the leaf temperature and transpiration, photosynthetic rate as well as stomatal conductance. The correlation is negative in case of stomatal conductance. The estimated parameters are all significant and the explained variance of the model is high (0.777).

\section{Stomatal conductance of leaves}

We have found significant differences in stomatal conductance between species and genera even under similar temperature which suggests again different responses to environmental conditions (Fig. 3). 


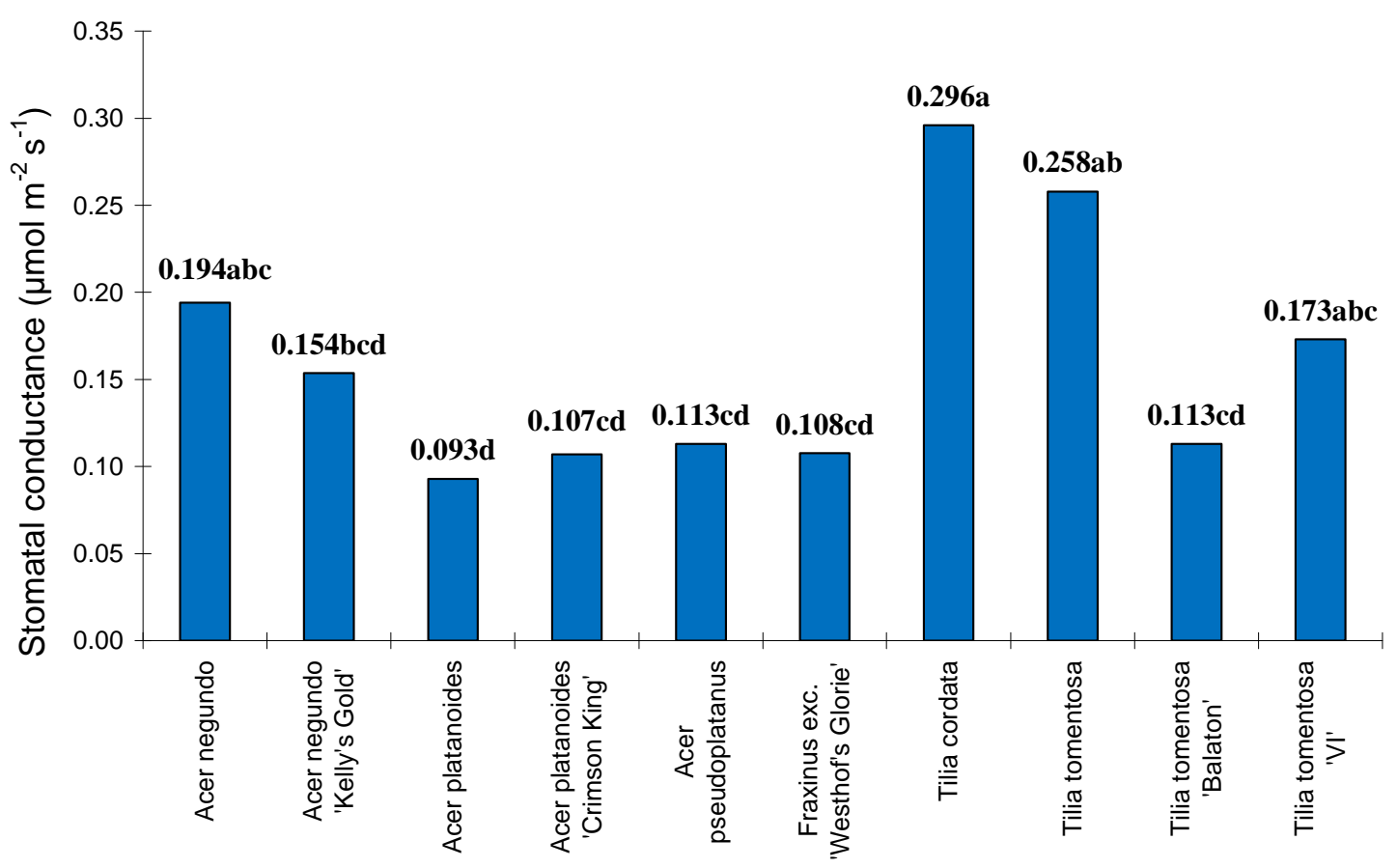

Figure 3. Stomatal conductance $\left(\mu \mathrm{mol} \mathrm{m} \mathrm{m}^{-2} \mathrm{~s}^{-1}\right.$ with the mean values of the measured plants. Different letters mean significant differences according to Tukey post hoc test $(p<0.05)$.

Table 2 summarizes the regression analysis results: the bivariate correlation between the stomatal conductance and the explaining variables such as transpiration, photosynthetic rate, leaf surface temperature and PAR, the estimated parameters, the $t$ values of the estimated parameters, the tolerance of the model variables, the $F$ value of the ANOVA model test with its degrees of freedom and the variance explained by the model.

The correlation between stomatal conductance and transpiration, photosynthetic rate as well as leaf surface temperature are all significant, the latter two variables are negatively correlated to stomatal conductance (Table 2). The estimated parameters are all significant and the explained variance is as high as 0.937 .

Table 2. Regression diagnostics of the model of stomatal conductance $\left(\mu \mathrm{mol} \mathrm{m} \mathrm{m}^{-2} \mathrm{~s}^{-1}\right)$

\begin{tabular}{|c|c|c|c|c|c|c|c|c|}
\hline \multicolumn{2}{|c|}{ Model } & \multirow{2}{*}{ Corr. $\mathbf{R}^{2}$} & \multirow{2}{*}{\multicolumn{2}{|c|}{ Parameters }} & \multirow{2}{*}{$t$} & \multirow{2}{*}{$\begin{array}{l}\text { Toler- } \\
\text { ance }\end{array}$} & \multirow{2}{*}{$\begin{array}{c}F \text { with } \\
\text { df }\end{array}$} & \multirow{2}{*}{$\begin{array}{c}\text { Variance } \\
\text { explained } \\
\text { by the } \\
\text { model }\end{array}$} \\
\hline $\begin{array}{c}\text { Dependent } \\
\text { variable }\end{array}$ & $\begin{array}{c}\text { Explaining } \\
\text { variables }\end{array}$ & & & & & & & \\
\hline \multirow{5}{*}{$\begin{array}{c}\text { Stomatal } \\
\text { conductance }\end{array}$} & constant & & $p_{0}$ & 0.208 & $9.62 * * *$ & - & \multirow{5}{*}{$\begin{array}{c}(4 ; 111) \\
414.27 \\
* * *\end{array}$} & \multirow{5}{*}{$0.937 * * *$} \\
\hline & transpiration & $0.924 * *$ & $p_{1}$ & 0.119 & $30.34 * * *$ & 0.42 & & \\
\hline & $\begin{array}{l}\text { photosynthetic } \\
\text { rate }\end{array}$ & $0.619 * *$ & $p_{2}$ & 0.004 & $6.80^{* * *}$ & 0.557 & & \\
\hline & $\begin{array}{l}\text { leaf surface } \\
\text { temperature }\end{array}$ & $0.504 * *$ & $p_{3}$ & -0.012 & $-10.20 * * *$ & 0.429 & & \\
\hline & PAR & $0.367 * *$ & $p_{4}$ & $-1.20 \mathrm{E}-05$ & $-3.52 * *$ & 0.649 & & \\
\hline
\end{tabular}




\section{Transpiration rate of the leaves}

The leaves of trees of different species also showed significant differences in transpiration rate (Fig. 4). The results revealed that varieties Acer platanoides, Acer platanoides 'Crimson King'. Acer pseudoplatanus and Fraxinus exc. 'Westhof's Glorie' showed low transpiration contrary to the other measured species of this genus.

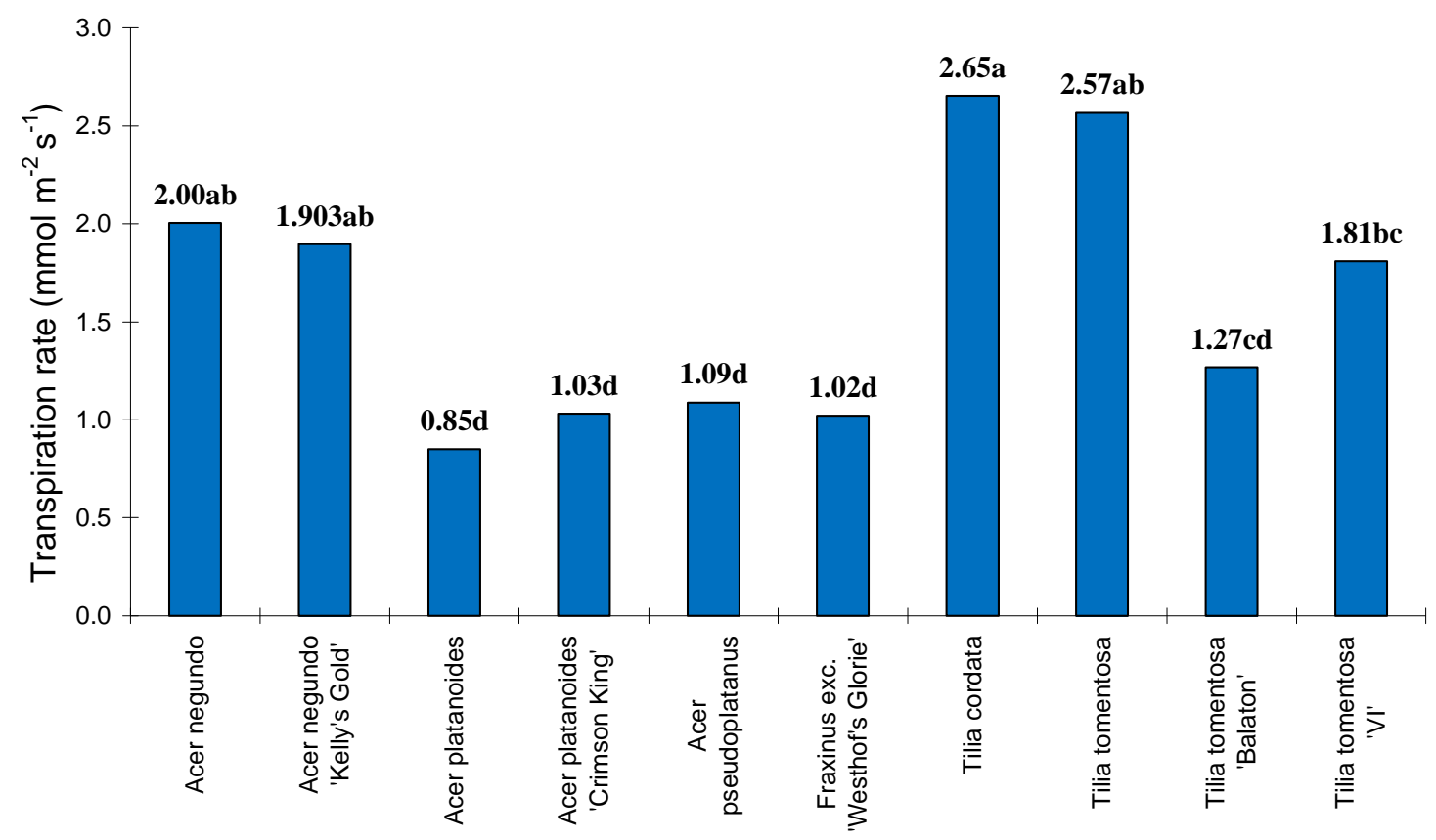

Figure 4. Transpiration rate $\left(\mathrm{mmol} \mathrm{m} \mathrm{m}^{-2} \mathrm{~s}^{-1}\right)$ with the mean values of the measured plants.

Different letters mean significant differences according to Tukey post hoc test $(p<0.05)$.

Leaves of the Tilia genus had high leaf surface temperature and transpired more in the measured period than leaves of other species measured at similar PAR values. In comparison to Prunus avium leaves measured by Gyeviki (2011), ornamental trees transpired significantly less on a leaf surface basis. The transpiration rate measured on Tilia tomentosa leaves is close to the rate measured by Noitsakis and Nastis (1995). Within the Acer genus assuming proportional transpiration and PAR values, Acer platanoides 'Crimson King' transpirated significantly less, while Acer negundo transpirated as double as the other Acer species.

Table 3 summarizes the regression analysis results: the bivariate correlation between the transpiration rate and the explaining variables such as stomatal conductance, photosynthetic rate, leaf surface temperature and PAR, the estimated parameters, the $t$ values of the estimated parameters, the tolerance of the model variables, the $F$ value of the ANOVA model test with its degrees of freedom and the variance explained by the model.

Strong correlation was found between transpiration rate and stomatal conductance (Table 3). This is in correspondence with the results Gortan et al. (2009) measured on Fraxinus ornus. The transpiration rate of the leaves correlates with leaf surface temperature, too (Table 1), the highest transpiration rate was measured on leaves showing leaf surface temperature above $25^{\circ} \mathrm{C}$.

The estimated parameters are all significant and the explained variance of the model is high (0.955). 
Table 3. Regression diagnostics of the model of transpiration rate $\left(\mu \mathrm{mol} \mathrm{m} \mathrm{m}^{-2} \mathrm{~s}^{-1}\right)$

\begin{tabular}{|c|c|c|c|c|c|c|c|c|}
\hline \multicolumn{2}{|c|}{ Model } & \multirow{2}{*}{ Corr. $\mathbf{R}^{2}$} & \multirow{2}{*}{\multicolumn{2}{|c|}{ Parameters }} & \multirow{2}{*}{$t$} & \multirow{2}{*}{$\begin{array}{l}\text { Toler- } \\
\text { ance }\end{array}$} & \multirow{2}{*}{$\begin{array}{l}F \text { with } \\
\text { df }\end{array}$} & \multirow{2}{*}{$\begin{array}{c}\text { Variance } \\
\text { explained } \\
\text { by the } \\
\text { model }\end{array}$} \\
\hline $\begin{array}{c}\text { Dependent } \\
\text { variable }\end{array}$ & $\begin{array}{c}\text { Explaining } \\
\text { variables }\end{array}$ & & & & & & & \\
\hline \multirow{5}{*}{ Transpiration } & constant & & $p_{0}$ & -1.799 & $-11.48 * * *$ & - & \multirow{5}{*}{$\begin{array}{c}(4 ; 111) \\
585.77 \\
* * *\end{array}$} & \multirow{5}{*}{$0.955^{* * *}$} \\
\hline & $\begin{array}{c}\text { stomatal } \\
\text { conductance }\end{array}$ & $0.924 * *$ & $p_{1}$ & 7.487 & $30.34 * * *$ & 0.583 & & \\
\hline & $\begin{array}{l}\text { photosynthetic } \\
\text { rate }\end{array}$ & $0.600 * *$ & $p_{2}$ & -0.023 & $-5.07 * * *$ & 0.484 & & \\
\hline & $\begin{array}{l}\text { leaf surface } \\
\text { temperature }\end{array}$ & $0.723 * *$ & $p_{3}$ & 0.109 & $13.34 * * *$ & 0.576 & & \\
\hline & PAR & $0.495 * *$ & $p_{4}$ & $1.03 \mathrm{E}-04$ & $3.72 * * *$ & 0.656 & & \\
\hline
\end{tabular}

${ }^{*} \mathrm{p}<0.05 ; * * \mathrm{p}<0.01 ; * * * \mathrm{p}<0.001$

\section{Photosynthetic rate of leaves}

Although Acer platanoides 'Crimson King' and Tilia cordata showed greater differences in stomatal conductance, their $\mathrm{CO}_{2}$ assimilation was higher which suggests differences in $\mathrm{CO}_{2}$ fixation capacity of leaves (Fig. 5). The genus Tilia showed highest net $\mathrm{CO}_{2}$ assimilation except for the tree 'Balaton' which was exposed to lower PAR value. Gyeviki (2011) measured similar $\mathrm{CO}_{2}$ fixation values on Prunus avium trees in a high density plantation. The photosynthetic activity of the leaves of other species was significantly lower compared to Tilia.

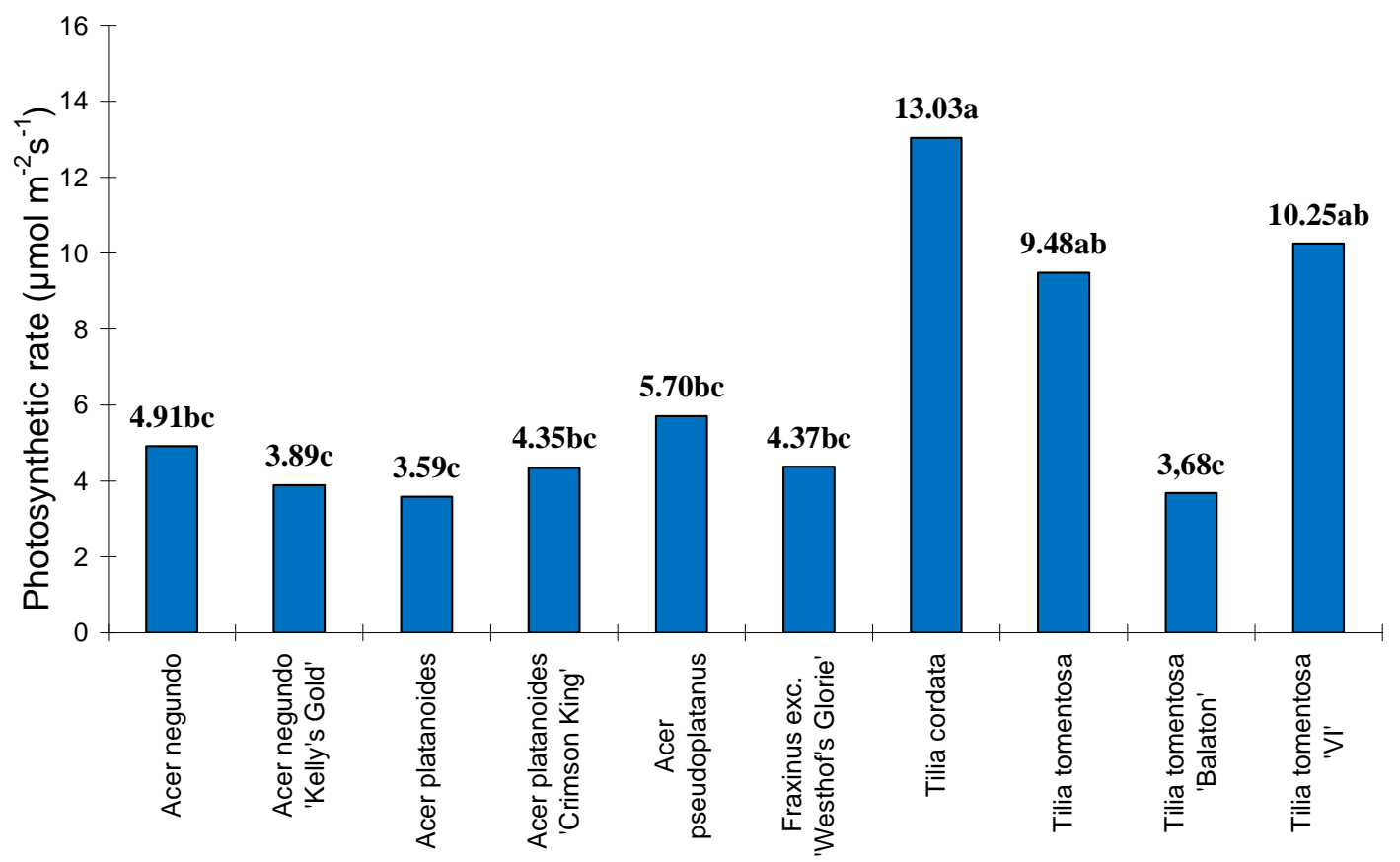

Figure 5. Photosynthetic rate $\left(\mu \mathrm{mol} \mathrm{m} \mathrm{m}^{-2} \mathrm{~s}^{-1}\right)$ with the mean values of the measured plant. Different letters mean significant differences according to Tukey post hoc test $(p<0.05)$. 
Table 4 summarizes the regression analysis results: the bivariate correlation between the photosynthetic rate and the explaining variables such as stomatal conductance, leaf surface temperature and PAR, the estimated parameters, the $t$ values of the estimated parameters, the tolerance of the model variables, the $F$ value of the ANOVA model test with its degrees of freedom and the variance explained by the model.

Table 4. Regression diagnostics of the model of the photosynthetic rate of the leaves ( $\left.m m o l ~ m^{-2} s^{-1}\right)$

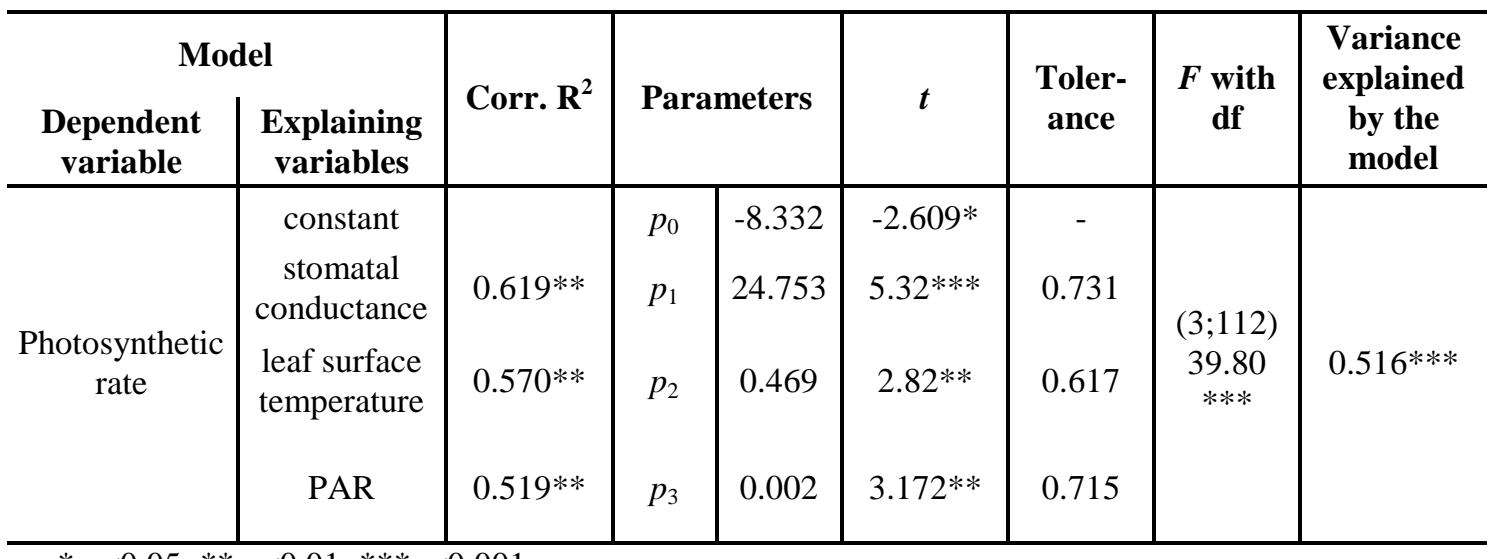

$* \mathrm{p}<0.05 ; * * \mathrm{p}<0.01 ; * * * \mathrm{p}<0.001$

The correlation of net $\mathrm{CO}_{2}$ assimilation rate of leaves showed significant correlation to stomatal conductance, leaf surface and PAR (Table 4). Though the estimated parameters are all significant together with the explained variance of the model (0.516), the latter value is the lowest compared to the other regression models which implies that other factors, like species or genus treats might be involved in correspondence to Endres et al. (2009) and Fini et al. (2010).

\section{Water use efficiency (WUE) of leaves}

Calculating the water use efficiency (WUE) significant differences were found between genera and species (Fig. 6). The leaves of Tilia species with high photosynthetic activity and high transpiration rate (Fig. 4 and Fig. 5) showed intermediate water use efficiency. According to our measurement Acer negundo and Acer negundo 'Kelly's Gold' have the lowest water use efficiency, here the low net $\mathrm{CO}_{2}$ assimilation was accompanied with high transpiration rate (Fig. 4 and Fig. 5). Acer platanoides showed the highest WUE. 


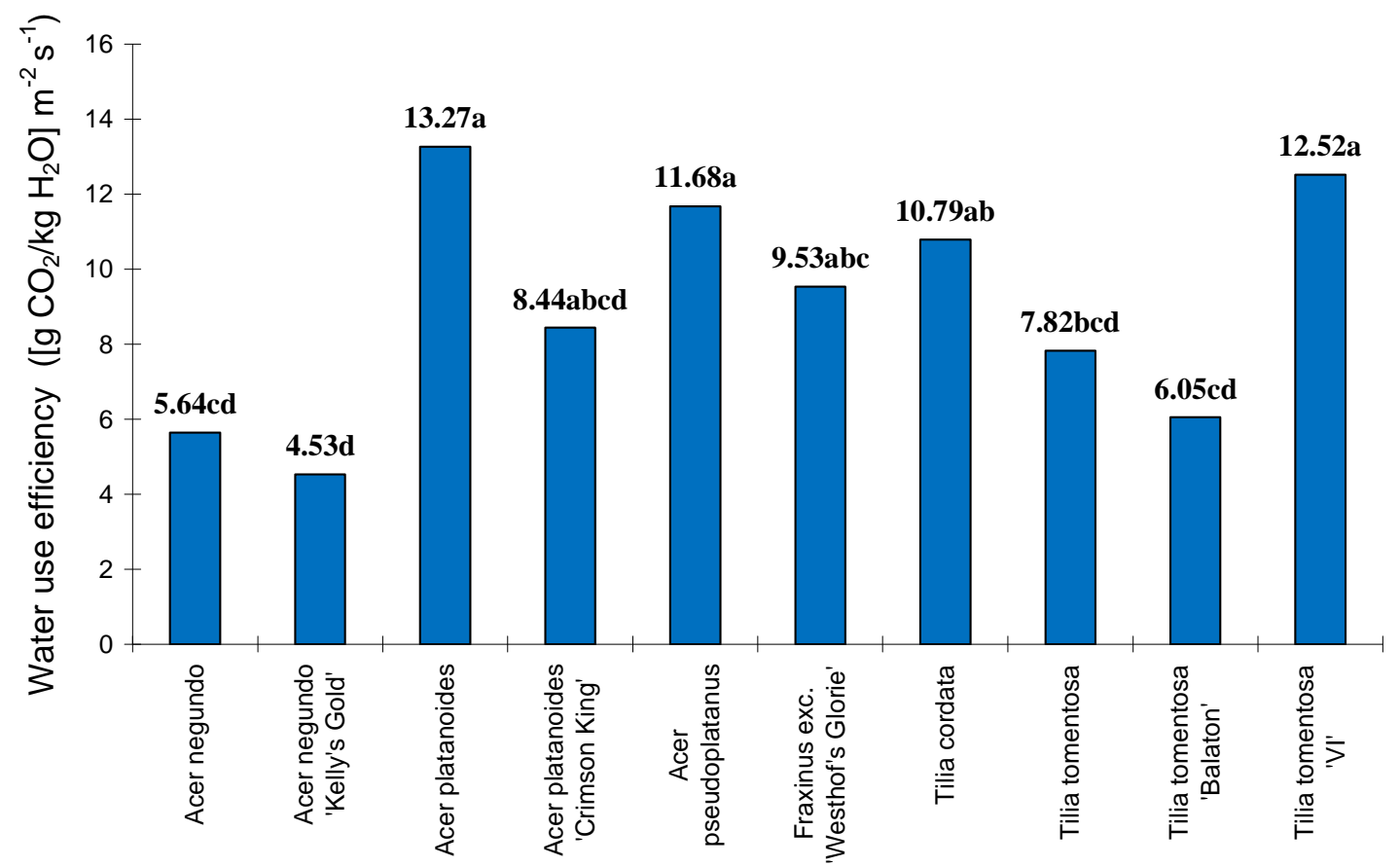

Figure 6. Water use efficiency of leaves on the investigated plants ([g $\left.\left.\mathrm{CO}_{2} / \mathrm{kg} \mathrm{H}_{2} \mathrm{O}\right] \mathrm{m}^{-2} \mathrm{~s}^{-1}\right)$. Different letters mean significant differences according to Games-Howell post hoc test $(p<0.05)$.

\section{Conclusions}

There are considerable differences found in net photosynthetic rate and transpiration rate in leaves of different species and genera. As a consequence, these plants have different capacity of environmental benefits.

We showed that transpiration rate was strongly influenced by leaf temperature and stomatal conductance. Since these variables are altering during the day and the vegetation period, an accurate comparison of genera, species or cultivars would be needed under the same environmental conditions.

Further on, for an exact evaluation of the $\mathrm{CO}_{2}$ assimilation capacity of the urban tree canopy and green space systems we should follow the daily and also the annual course of the activity of the leaves. To follow this course and to compare the species, varieties and site conditions more precisely, measurements should be carried out after the leaves have completely developed, through all day and in different periods of the year.

Only leaves exposed to direct sunlight were measured so far, which are playing the main role in photosynthesis, however, more shaded leaves also exploit some sunlight which implies that measuring them would raise new aspects and questions.

Our study confirmed that the stomatal conductance influences the transpiration rate and $\mathrm{CO}_{2}$ assimilation rate strongly. By observing the daily and annual alteration of stomatal conductance we could get a more accurate aspect about the photosynthesis and the water use of each tree and about their environmental value.

Acknowledgements. Our research was supported by TÁMOP-4.2.1/B-09/1/KMR-2010-0005 project. 


\section{REFERENCES}

[1] Anderson, J.E. (1982): Factors controlling transpiration and photosynthesis in Tamarix Chinensis Lour. - Ecology 63(1): 48-56.

[2] Box, G.E.P., Cox, D.R. (1964): An analysis of transformations. - Journal of the Royal Statistical Society, Series B 26 (2): 211-252.

[3] Bucci, S.A., Scholz, F.G., Goldstein, G., Meinzer, F.C., Hinojosa, J.A., Hoffmann, W.A., Franco, A.C. (2004): Processes preventing nocturnal equilibration between leaf and soil water potential in tropical savanna woody species. - Tree Physiol. 24: 1119-1127.

[4] Ceulemans, R., Mousseau, M. (1994): Effects of elevated atmospheric $\mathrm{CO}_{2}$ on woody plants. - New Phytologist 127: 425-446.

[5] Curtis, P.S. (1996): A meta-analysis of leaf gas exchange and nitrogen in trees grown under elevated carbon dioxid. - Plant, Cell and Environment 19: 127-137.

[6] D'Agostino, R.B., Belanger, A., D'Agostino, R.B. Jr. (1990): A suggestion for using powerful and informative tests of normality. - The American Statistician 44(4): 316-321.

[7] Daley, M.J., Phillips, N.G. (2006): Interspecific variation in nighttime transpiration and stomatal conductance in a mixed New England deciduous forest. - Tree Physiol. 26: 411-419.

[8] Endres, L., Camara, C.A., Ferreira, V.M., Silva, J.V. (2009): Morphological and photosynthetic alterations in the Yellow-ipe, Tabebuia chrysotricha (Mart. Ex DC.) Standl., under nursery shading and gas exchange after being transferred to full sunlight. Agroforest Syst. 78: 287-298.

[9] Fini, A., Ferrini, F., Frangi, P., Piatti, R., Amoroso, G. (2010): Effects of shading on growth, leaf gas exchange and chlorophyll fluorescence of three container grown shrubs. - Acta Hort. (ISHS) 885: 109-117.

[10] Gortan, E., Nardini, A., Gascó, A., Salleo, S. (2009): The hydraulic conductance of Fraxinus ornus leaves is constrained by soil water availability and coordinated with gas exchange rates. - Tree Physiology 29. 529-539.

[11] Grulke, N.E., Alonso, R., Nguyen, T., Cascio, C., Dobrowolski, W. (2004): Stomata open at night in pole-sized and mature ponderosa pine: implications for $\mathrm{O} 3$ exposure metrics. Tree Physiol. 24: 1001-1010.

[12] Gyeviki, M. (2011): Cseresznye oltványok produktivitásának egyes tényezői. - Doktori értekezés, Budapesti Corvinus Egyetem

[13] Heath, J., Kerstiens, G. (1997): Effects of elevated $\mathrm{CO}_{2}$ on leaf gas exchange in beech and oak at two levels of nutrient supply: consequences for sensitivity to drought in beech. - Plant, Cell and Environment 20: 57-67.

[14] Hrotkó, K. (2002): A térállás és a tenyészterület optimalizálás összefüggései orsó koronájú intenzív ültetvényekben. - Kertgazdaság 34(4): 1-9.

[15] Jószainé Párkányi, I. (2007): Zöldfelület-gazdálkodás, parkfenntartás. - Mezőgazda kiadó, Budapest

[16] Leuzinger, S., Vogt, R., Körner, C. (2010): Trees surface temperature in an urban environment. - Agricultural and Forest Meteorology 150(1): 56-62.

[17] Noitsakis, B., Nastis, A. (1995): Seasonal changes of water potential, stomatal conductance and transpiration in the leaf of cherry trees grown in shelter. - In Sylvopastoral systems. Environmental, agricultural and economic sustainability. Zaragoza, CIHEAM-IAMZ, 1995. p. 267-270.

[18] Radó, D. (1999): Bel- és külterületi fasorok EU-módszer szerinti értékelése. A Lélegzet. 1999/7-8.

[19] Radó, D. (2001): A növényzet szerepe a környezetvédelemben. - Budapest Kiadó.

[20] Rodrigues, B.M., Souza, B.D., Nogueira, R.M., Santos, M.G. (2010): Tolerance to water deficit in young trees of jackfruit and sugar apple. - Revista Ciencia Agronomica 41(2): 245-252.

[21] Snyder, K.A., Richards, J. H., Donovan, L.A. (2003): Nighttime conductance in C3 and C4 species: do plants lose water at night? - J. Exp. Bot. 54: 861-865. 